\title{
Upaya Meningkatkan Kemampuan Pemecahan Masalah Matematis dan Aktivitas Siswa Melalui Pembelajaran Kooperatif Learning Tipe Jigsaw di Kelas II Sekolah Dasar
}

\author{
Efforts to Improve Problem Solving Mathematical and \\ Activity Student through Cooperative Learning Learning \\ Type Jigsaw in Second Class Elementary School
}

\author{
HANI HANDAYANI \\ STKIP Sebelas April Sumedang \\ JIn. Budaya No. 7, Kotakaler, Sumedang, 45621, Indoenesia. \\ Email: hanihandayanipasca@gmail.com
}

\begin{abstract}
The problems in this research are the low learning activity experienced by the students and the students' problem solving ability of mathematics. The purpose of this research is to improve the students' ability in solving mathematical problems and the students' learning activities through Jigsaw cooperative learning, particularly on the multiplication materials in second grade class of SDN Tangsungsari I, Kabupaten Sumedang. This research is a classroom action research conducted in two cycles. The subjects of the study were the 33 students of 2 nd grade class of SDN TanjungSari 1, Kabupaten Sumedang. The object of this research is the implementation of Jigsaw cooperative learning. The research instrument are using an essay test, which its validity and reliability has been tested, and also conducting observation on the students' learning activity. The results show that the average of student learning activities on the first cycle values 60 . In the second cycle, the learning activitivity in the first cycle, reaching the value of 65 , has been increased on the second cycle reaching the value of 80 .
\end{abstract}

Keywords: Learning activity, problem solving of mathematical, and cooperatife learning tipe Jigsaw.

\begin{abstract}
Abstrak
Permasalahan dalam penelitian ini adalah rendahnya aktivitas dan kemampuan pemecahan masalah siswa. Tujuan penelitian ini adalah untuk meningkatkan kemampuan pemecahan masalah matematika dan aktivitas siswa melaluli pembelajaran kooperatif learning tipe Jigsaw pada materi perkalian di kelas II SDN Tanjungsari 1 Kabupaten Sumedang. Metode penelitian yang digunakan adalah penelitian Tindakan Kelas dengan tindakan sebanyak sua siklus. Dalam penelitian ini instrument yang digunakan adalah tes dengan jenis soal essay yang telah diuji validasi dan reliabilitasnya dan lembar observasi untuk mengobservasi aktivitas belajar siswa. Berdasarkan hasil penelitian, diperoleh rata-rata aktivitas belajar siswa pada siklus I dengan nilai 60. Pada siklus II telah meningkat dengan nilai rata-rata 81. Demikian pula kemampuan pemecahan masalah matematika pada siklus I mendapatkan nilai 65, pada siklus kedua telah meningkat dengan nilai 80.
\end{abstract}

Kata Kunci: Aktivitas belajar, kemampuan pemecahan masalah matematika siswa, dan kooperatif learning tipe Jigsaw.

\section{Pendahuluan}

Pendidikan matematika memiliki peran penting untuk mengembangkan sumber daya manusia yang berkualitas. Siswa sebagai sumber daya manusia harus memiliki kemampuan berfikir secara matematis. Kemampuan ini sangat diperlukan agar siswa memahami konsep matematika yang sedang dipelajari dan dapat mengaplikasikannya dalam kehidupan sehari-hari, selain itu dijelaskan bahwa mata pelajaran matematika perlu diberikan kepada semua peserta didik mulai dari sekolah dasar untuk membekali peserta didik dengan kemampuan berpikir logis, analitis sistematis, kritis, dan kreatif, serta kemampuan berkerjasama. 
Kemendikbud 2013 (Fuadi, dkk, 2016: 47) memaparkan tujuan dari pembelajaran matematika menekankan pada dimensi pedagogik modern dalam pembelajaran, yaitu menggunakan pendekatan scientific (ilmiah). Dalam pembelajaran matematika kegiatan yang dilakukan yaitu mengamati, menanya, mencoba, menalar, menyaji, dan mencipta.Untuk mendukung siswa melakukan kegiatan-kegiatan tersebut, salah satu kemampuan yang harus dikembangkan adalah kemampuan pemecahan masalah matematika.

Kemampuan pemecahan masalah merupakan hal yang penting untuk dimiliki siswa sekolah dasar. Melalui kemampuan pemecahan masalah siswa dapat mengembangkan kemampuan berpikir siswa untuk dapat menghubungkan pengetahuan dan keterampilan yang telah dimilikinya untuk memecahkan permasalahan yang bersifat tidak rutin. Sebagaimana pendapat Leeuw (Hendriana, 2002: 13) menjelaskan bahwa belajar memecahkan masalah pada hakikatnya adalah belajar berpikir atau belajar bernalar untuk mengaplikasikan pengetahuan-pengetahuan yang telah diperoleh sebelumnya untuk memecahkan masalah-masalah baru yang belum pernah dijumpainya. Kemampuan pemecahan masalah berkaitan dengan kemampuan berpikir siswa. Karena itu agar siswa dapat menyelesaikan masalah yang tidak rutin diperlukan kemampuan berpikir yang tinggi.

Kenyataanny kemampuan pemecahan masalah matematika kurang dikembangbangkan dalam pembelajaran sehingga mengakibatkan rendahnya kemampuan pemecahan masalah dan siswa. Rendahnya kedua kemampuan tersebut dapat dilihat dari hasil laporan The Trends in International Mathematics and Science Study (TIMSS) tahun 2011 (Fachrurazi, 2011:77) yang menunjukan bahwa Indonesia berada pada peringkat 36 dari 48 negara. Hasil TIMSS mengungkapkan bahwa kemampuan matematis siswa Indonesia dalam mengerjakan soal-soal tidak rutin sangat lemah, sedangkan untuk mengerjakan soalsoal tidak rutin berkaitan dengan kemampuan pemecahan masalah matematika.

Selain itu menurut hasil Tim Survey IMSTEP-JICA (Fachrurazi, 2011: 78) menemukan sejumlah kegiatan yang dianggap sulit oleh siswa untuk mempelajarinya dan oleh guru untuk mengajarkannya antara lain, pembuktian pemecahan masalah yang memerlukan penalaran matematis, menemukan, generalisasi atau konjektur, dan menemukan hubungan antara data-data atau fakta yang diberikan. Semua kegiatan tersebut jelas merupakan kegiatan yang menuntut kemampuan pemecahan masalah Dengan demikian dapat disimpulkan bahwa hasil survei tersebut menemukan bahwa siswa mengalami kesulitan jika dihadapkan kepada persoalan-persoalan yang bersifat tidak rutin yang memerlukan kemampuan pemecahan masalah

Fakta lain, berdasarkan kegiatan observasi di lapangan siswa cenderung belajar matematika sebagai topik yang kaku berdasarkan aturan yang baku yang memungkinkan hanya satu jawaban yang benar dalam menjelaskan suatu jawaban, siswa tidak diberikan kesempatan untuk menggunakan pemikirannya dalam memunculkan ide-idenya sendiri. Guru dalam pembelajaran kurang memberikan kesempatan kepada siswa untuk menemukan konsep-konsep pembelajaran sendiri sesuai dengan pengalamannya. Hal ini menyebabkan kemampuan siswa dalam pemecahan masalah tidak berkembang.

Selain itu berdasarkan hasil observasi di SDN Tanjungsari 1 Kabupatean Sumedang di kelas II, diperoleh data dalam pembelajaran matematika yang berkaitan dengan penyelesaian soal cerita yang membutuhkan kemampuan pemecahan masalah dari 33 siswa terdapat 10 siswa yang hasil belajarnya sudah mencapai KKM, dan 23 siswa masih di bawah KKM. Hal ini menunjukan bahwa kemampuan pemecahan masalah matematika masih rendah.

Sebagai upaya dalam mengembangkan kemampuan pemecahan masalah matematika siswa, maka diperlukan desain pembelajaran matematika yang dapat menfasilitasi kemampuan tersebut. Untuk meningkatkan kemampuan pemecahan masalah dalam pembelajaran siswa dilibatkan dalam pembelajaran berbasis masalah yang sesuai dengan kehidupan sehari-hari siswa. Selain itu dalam pembelajaran siswa perlu diberi kesempatan untuk mengkonstruk pengetahuannya sendiri, memunculkan ideidenya sendiri, siswa juga difasilitasi dalam kegiatan diskusi karena melalui kegiatan diskusi siswa akan saling bertukar pendapat. Dalam kegiatan diskusi siswa akan belajar untuk menerima dan menolak argumen orang lain yang disertai alasan-alasan yang rasional. Kegiatan ini akan membantu berkembangnya 
kemampuan berpikir kritis siswa.

Berdasarkan hasil observasi di lapangan selain memiliki manfaat yang positif, kegiatan diskusi dalam pembelajaran terkadang berdampak negatif. Bagi siswa yang tidak terbiasa dengan kegiatan diskusi dan berkerjasama akan membuat suasana pembelajaran menjadi kurang kondusif. Apabila siswa diberi persoalan dan harus diselesaikan secara kelompok atau berdiskusi, biasanya hanya siswa-siswa tertentu atau siswa-siswa yang pintar saja yang menyelesaikan persoalan tersebut sedangkan anggota kelompok yang lainnya tidak ikut berpartisipasi. Oleh karena itu guru perlu memiliki keterampilan dalam mengondisikan kelas dalam kegiatan diskusi serta guru perlu memilih desain pembelajaran kelompok yang efektif dalam pembelajaran sehingga semua siswa ikut berpartisipasi aktif dalam pembelajaran, tujuan pembelajaran dapat tercapai dan khususnya dalam hal ini kemampuan pemecahan masalah matematika seluruh siswa dapat dikembangkan.

Desain pembelajaran yang dapat memfasilitasi seluruh siswa agar dapat berpartisipasi dalam kegiatan diskusi yaitu kooperatif tipe Jigsaw. Model kooperatif tipe Jigsaw diduga dapat meningkatkan kemampuan pemecahan masalah matematika setiap siswa karena dalam kegiatan diskusi siswa dikelompokkan dalam tim ahli dan tim asal untuk memecahkan masalah matematika. Siswa dituntut untuk memahami/ menyelesaikan permasalahan yang berbedabeda dalam kelompok asal. Kemudian siswa berdiskusi untuk memecahkan permasalahan dengan kelompok ahli, di mana anggota semua kelompok ahli memiliki tugas yang sama. Setelah masalah diselesaikan, semua anggota kelompok ahli kembali ke kelompok asalnya untuk menyampaikan hal yang telah didiskusikannya di kelompok ahli. Melihat alur kegiatan diskusi dalam kooperatif tipe Jigsaw semua anggota kelompok memiliki tanggung jawab dalam menyelesaikan masalah.

Berdasarkan permasalahan di atas maka rumusan masalah dalam penelitian ini adalah: (1)Bagaimana kemampuan pemecahan masalah matematis siswa melalui pembelajaran Kooperatife Learning Tipe Jigsaw pada materi perkalian di kelas II SDN Tanjungsari 1 Kabupaten Sumedang? 2) Bagaimana aktivitas belajar siswa memlalui pembelajaran Kooperatife Learning Tipe Jigsaw pada materi perkalian di kelas II SDN tanjungsari 1 Kabupaten Sumedang?

\section{Pembelajaran Cooperative Learning Tipe Jigsaw}

Cooperative learning adalah model pembelajaran yang mencakupi suatu kelompok kecil siswa yang berkerjasama dalam tim untuk menyelesaikan sebuah masalah, menyelesaikan suatu tugas, atau mengerjakan sesuatu untuk mencapai tujuan bersama lainnya (Suherman, 2001: 218). Sama halnya dengan pendapat yang dikemukakan oleh Johnson \& Johnson (Isjoni, 2009: 45) bahwa cooperative learning adalah mengerjakan sesuatu bersama-sama dengan saling membantu satu sama lainnya sebagai satu tim untuk mencapai tujuan bersama.

Model pembelajaran kooperatif berbeda dengan belajar dengan kelompok biasa. Suherman (2001:31) menjelaskan bahwa bukanlah cooperative learning jika para siswa duduk bersama dalam kelompok-kelompok kecil tetapi mempersilahkan salah seorang diantaranya untuk menyelesaikan seluruh pekerjaan kelompok. Jadi dapat disimpulkan bahwa pembelajaran kooperatif adalah pembelajaran dalam kelompok kecil yang bekerjasama dalam memecahkan masalah yang diberikan, di mana semua angggota kelompok harus ikut berpastisipasi dalam kegiatan diskusi sehingga akan tercapai tujuan bersama.

Menurut Lie (2007: 29) "terdapat unsur-unsur dasar pembelajaran cooperative learning yang membedakannya dengan pembagian kelompok yang dilakukan asalasalan". Unsur-unsur model pembelajaran cooperative tersebut (Roger dan David Johson dalam Lie, 2009: 31) yaitu: saling kebergantungan yang positif, tanggungjawab perseorangan, tatap muka, komunikasi antar anggota, dan evaluasi proses kelompok.

Terdapat berbagai macam tipe dalam model kooperatif. Salah satunya yaitu model kooperatif tipe Jigsaw. Model kooperatif tipe Jigaw dikembangkan oleh Aronson. Dalam tipe Jigsaw guru perlu memperhatikan pengetahuan yang telah dimiliki oleh siswa yang diperolehnya melalui pengalamannya dan membantu siswa untuk mengaitkan pengetahuan dengan kehidupan nyata agar pembelajaran lebih bermakna. Terdapat beberapa tahap dalam model kooperatif tipe Jigsaw (Isjoni, 2009: 57) yaitu: tahap pertama siswa dikelompokan dalam bentuk kelompok-kelompok kecil yang terdiri dari 4-6 orang. Untuk mengoptimalkan manfaat pembelajaran kooperatif, anggota kelompok disusun secara heterogen, baik dari segi 
kemampuan ataupun dari karakteristik lainnya. Kelompok yang telah disusun dinami tim "asal"

Tahap kedua materi pembelajaran dibagikan kepada setiap kelompok menurut anggota tim. Tiap-tiap tim diberikan satu set materi/tugas yang lengkap dan masingmasing individu ditugaskan untuk memilih topik masing-masing sesuai dengan materi yang telah ditentukan. Tahap tiga, siswa dipisahkan menjadi kelompok/ tim "ahli" yang terdiri dari seluruh siswa yang memunyai topik/tugas yang sama. Di tim ahli, siswa saling membantu mempelajari materi atau menyelesaikan tugas untuk diinformasikan kepada tim asal. Tahap keempat setelah siswa mempelajari materi/menyelesaikan tugas di tim ahli, kemudian siswa kembali kepada ke tim asli untuk menginformasikan materi tersebut kepada tim asal.

Model kooperatif tipe Jigsaw efektif digunakan dalam pembelajaran karena melihat tahap-tahap dari tipe Jigsaw memungkinkan seluruh siswa dapat aktif dalam kegiatan diskusi karena masingmasing telah memiliki tanggungjawab untuk menyelesaikan tugasnya masing-masing yang kemudian harus diinformasikan kepada teman sekelompoknya.

\section{Kemampuan Pemecahan Masalah}

Dalam pembelajaran matematika kemampuan pemecahan masalah merupakan salah satu tujuan yang harus dicapai. Maka dari itu guru matematika harus berusaha agar siswa memiliki kemampuan dalam pemecahan masalah matematika. Polya (Saija, 2008: 28) menyatakan bahwa tugas utama guru matematika di sekolah ialah menggunakan segenap kemampuannya untuk mengembangkan kemampuan siswa untuk menyelesaikan atau memecahkan masalah matematika.

Masalah dapat diartikan suatu kesenjangan (gap) kondisi yang ada dengan tujuan yang diinginkan (Huyes dalam Suwangsih, 2006: 126). Sedangkan Suherman (2001: 86) mengemukakan bahwa suatu masalah biasanya memuat suatu situasi yang mendorong seseorang menyelesaikannya akan tetapi tidak tahu secara langsung apa yang harus dikerjakan untuk dapat menyelesaikan masalah tersebut. Selanjutnya dalam Webster's New Twentieth Century Unabridged Dictionary, Matematika Sebagai Pemecahan Masalah mengajukan dua definisi berbeda tentang masalah sebagai berikut: (1)In mathematics, a problem is anything required to be done or that requires the doing of something. (2)A problem is a question ... that is perplexing or difficult.

Suatu permasalahan bersifat relatif. Suatu soal yang dianggap masalah untuk seseorang belum tentu itu soal tersebut merupakan masalah bagi siswa yang lainya. Oleh Karena itu untuk dapat meningkatkan kemampuan pemecahan masalah matematika guru harus berhati-hati dalam membuat soal. Soal-soal yang dibuat harus merupakan soalsoal yang tidak rutin, sehingga kemampuan pemecahan masalah matematika dapat dikembangkan. Berhubungan dengan hal ini, maka guru sebaiknya memiliki keterampilan dalam membuat soal matematika, memilih antara masalah rutin dan masalah tidak rutin.

Suherman (2007: 85) mengemukakan untuk mengembangkan kemampuan pemecahan masalah matematika pada siswa, hal yang perlu ditingkatkan adalah adalah kemampuan menyangkut berbagai teknik dan strategi pemecahan masalah. Menurut Polya (Suherman, 2007: 91) dalam pemecahan suatu masalah terdapat empat langkah yang harus dilakukan siswa, antara lain: (1)Memahami masalah yang diberikan, (2)Merencanakan pemecahan masalah, (3) Menyelesaikan masalah sesuai dengan yang telah direncanakan pada tahap kedua, (4) Memeriksa kembali hasil yang diperolehnya (looking back)

Empat tahap pemecahan masalah tersebut berkaitan erat dengan kemampuan pemecahan masalah matematika dan keempat tahap pemecahan masalah tersebut penting untuk dikembangkan untuk meningkatkan kemampuan pemecahan masalah matematika. Sementara itu, Krulik dan Rudnik (Lidinillah, 2008: 2) mengenalkan 5 (lima) tahapan pemecahan masalah yang mereka sebut sebagai heuristik. Heuristik adalah langkahlangkah dalam menyelesaikan sesuatu tanpa harus berurutan mereka mengkhususkan langkah ini dapat diajarkan di sekolah dasar untuk mengembangkan kemampuan pemecahan masalah. Lima langkah tersebut adalah: (1) Read and Think (Membaca dan Berpikir), yang meliputi kegiatan mengidentifikasi fakta, mengidentifikasi pertanyaan, memvisualisasikan situasi, menjelaskan setting, dan menentukan tindakan selanjutya, (2) Explore and Plan (Ekplorasi dan Merencanakan), yang meliputi kegiatan: mengorganisasikan 
informasi, mencari apakah ada informasi yang sesuai/diperlukan, mencari apakah ada informasi yang tidak diperlukan, mengambar/ mengilustrasikan model masalah, dan membuat diagram, tabel, atau gambar, (3) Select a Strategy (Memilih Strategi), yang meliputi kegiatan : menemukan/ membuat pola, bekerja mundur, coba dan kerjakan, simulasi atau eksperimen, Penyederhanaan atau ekspansi, membuat daftar berurutan, deduksi logis, dan membagi atau mengkategorikan permasalahan menjadi masalah sederhana, (4) Find an Answer (Mencari Jawaban), yang meliputi kegiatan: memprediksi, menggunakan kemampuan berhitung, menggunakan kemampuan aljabar, menggunakan kemampuan geometris, dan menggunakan kalkulator jika diperlukan., (5) Reflect and Extend (Refleksi dan Mengembangkan), memeriksa kembali jawaban, menentukan solusi alternatif, mengembangkan jawaban pada situasi lain, mengembangkan jawaban (generalisasi atau konseptualisasi), mendiskusikan jawaban, dan menciptakan variasi masalah dari masalah yang asal.

\section{Metodologi Penelitian}

Penelitian ini merupakan penelitian tindakan kelas. Model penelitian tindakan kelas dilatar belakangi oleh kenyataan bahwa kemampuan pemecahan masalah dan aktivitas belajar siswa di sekolah dasar pada umumny masih rendah, sehingga perlu diupayakan suatu tindakan untuk memecahkan permasalahan tersebut.

Model penelitian tindakan kelas yang digunakan dalam penelitian ini adalah model spiral sebagaimana dikemukakan oleh Kemmis dan MC. Taggart, dengan langkahlangkah (1) persiapan, (2) pelaksanaan, (3) observasi, dan (4) reflekasi. Penelitian ini dilakukan dalam 2 siklus. Adapun langkah langkah dalam setiap siklus terdiri dari: (1) Persiapan. Kegiatan yang dilakukan pada tahap persiapan adalah, membuat perencanaan proses pembelajaran, yaitu RPP, menyiapkan media pembelajaran yang akan digunakan, menyiapkan lembar kerja siswa, membuat instrumen tes kemampuan pemecahan masalah matematis, dan membuat instrumen lembar observasi aktivitas siswa. (2) Pelaksanaan, kegiatan yang dilakukan adalah melaksanakan seluarih kegiatan yang terdapat dalam kegiatan perencanaan. (3) Observasi, Kegiatan obersevasi yang dilaksanakan yaitu mengobservasi aktivitas siswa selama melaksanakan prosesn pembelajaran sesuai indikator aktivitas belajar yang akan di ukur. (4) Refleksi. Kegiatan refleksi dilaksanakan pada saat akhir pembelajaran. Hasil refleksi pada siklus I merupakan acuan bagi peneliti untuk melakukan tindakan perbaikan pada pelaksanaan proses pembelajaran di siklus ke II.

Penelitian ini dilaksanakan di SDN Tanjungsari 1 Kabupaten Sumedang yang dilaksanakan semester 2, bulan Maret 2016 Sedangkan yang menjadi subjek penelitian adalah siswa kelas II SDN Tanjungsari 1 Sumedang.

Data dalam penelitian ini merupakan dari hasil evaluasi dan pengamatan selama proses pembelajaran dalam penelitian. Data yang diperoleh dengan cara sebagai berikut: (1) Tes, tes dilaksanakan setiap akhir proses pembelajaran dengan menggunakan instrumen tes tulis, soal yang diberikan berupa 5 soal cerita /uraian. (2) Observasi, observasi yang dilakukan dengan menggunakan lembar observasi aktivitas siswa. Observasi siswa bertujuan untuk melihat aktivitas siswa pada saat proses pembelajaran

\section{Hasil dan Pembahasan}

Pelaksanaan pembelajaran kooperatif learning tipe jigsaw pada materi perkalian di siklus 1 , belum memperlihatkan hasil yang memuaskan. Pada saat proses pembelajaran siswa masih merasa binggung dengan pembelajaran secara berkelompok, terlihat aktivitas siswa masih kurang dalam kegiatan kelompok, baik dari aspek kerjasama, aspek keaktifan siswa, dan aspek tanggung jawab siswa. Pada saat siswa berkumpul dikelompok ahli terlihat hanya beberapa siswa saja yang mau bekerjasama dalam mengerjakan soal yang diberikan guru. Hal ini berdampak pada saat siswa diminta untuk kembali berkumpul di kelompok asal, siswa yang tidak bekerjasama dan tidak aktif dalam mengerjakan soal dikelompok ahli akan mengalami kesulitan saat harus menerangkan hasil pengerjaan tugasnya kepada anggota kelompok asal.

Hasil observasi aktivitas siswa diperoleh nilai pada aspek kerjasama, memperoleh nilai 65. Pada aspek keaktifan memperoleh nilai 55, dan pada aspek tanggungjawab siswa memperoleh nilai 60 . Nilai rata-rata aktivitas siswa yaitu 60 . Masih rendahnya aktivitas siswa di siklus 1 berdampak pada hasil kemampuan pemecahan masalah matematis 
siswa. Dari hasil tes, sebagian siswa belum mencapai ketuntasan belajar (KKM) yaitu 68 , dari 33 siswa, 10 orang siswa yang telah mencapai ketuntasan belajar dan sisanya 23 siswa tidak tuntas dengan nilai rata-rata kemampuan pemecahan masalah matematis yaitu 65

Pada siklus II, pelaksanaan proses pembelajaran sudah terjadi peningkatan yang signifikan. Dari hasil observasi siswa selama proses pembelajaran. Ketiga aspek aktivitas siswa yang diobservasi yaitu aspek kerjasama, aspek keaktifan, dan aspek tanggungjawab sudah mengalami peningkatan. Pada aspek kerjasama memperoleh nilai 78, pada aspek keaktifan 80 , dan pada aspek tanggungjawab 85, dengan nilai rata-rata aktivitas siswa pada siklus II yaitu 81 . Dalam pelaksanaan proses pembelajaran di siklus 2 terlihat siswa lebih antusian dan termotivasi. Hal ini disebabkan karena guru memberikan banyak reward kepada siswa. Dalam proses pembelajaran siswa sudah lebih kondusif pada saat melaksanakan tugas nya baik di kelompok ahli maupun di kelompok asal. Siswa pun lebih aktif dalam kegiatan diskusi kelas, aktif dalam menjawab pertanyaan guru maupun pertanyaan dari teman sekelas. Meningkatnya aktivitas siswa dalam proses pembelajaran berdampak pada meningkatnya kemampuan pemecahan masalah matematis siswa. Dari hasil tes pada siklus 2, diperoleh dari 33 siswa, 30 orang yang nilainya sudah mencapai KKM, dan 3 orang yang belum mencapai KKM. Nilai rata-rata kemampuan pemecahan masalah matematis siswa yaitu 80. Gambaran peningkatan aktivitas dan kemampuan pemecahan masalah matematis dapat dilihat pada tabel di bawah ini.

Tabel 1. Nilai Aktivitas Siswa

\begin{tabular}{|l|c|c|}
\hline \multicolumn{1}{|c|}{ Aspek } & Siklus 1 & Siklus 2 \\
\hline Kerjasama & 65 & 78 \\
\hline Keaktifan & 55 & 80 \\
\hline Tanggungjawab & 60 & 85 \\
\hline Rata-rata Nilai & $\mathbf{6 0}$ & $\mathbf{8 1}$ \\
\hline
\end{tabular}

Tabel 2. Nilai Kemampuan Pemecahan Matematis siswa

\begin{tabular}{|c|c|}
\hline Siklus & Nilai \\
\hline Siklus 1 & 65 \\
\hline Siklus 2 & 80 \\
\hline
\end{tabular}

Berdasarkan hasil yang diperoleh dari pelaksanaan siklus I dan II, terjadi peningkatan aktivitas belajar dan kemampuan pemecahan masalah matematis siswa. Aktivitas belajar dan kemampuan pemecahan matematis siswa yang meningkatan disebabkan karena penggunaan model pembelajaran kooperatif tipe Jigsaw. Dengan pembelajaran tipe Jigsaw proses pembelajaran dilaksanakan secara berkelompok. Kegiatan kelompok yang dilaksanakanpun berbeda dengan kegiatan kelompok biasa. Dalam kooperatif tipe Jigsaw, siswa memiliki tugas masing-masing yang harus diselesaikan bersama dikelompok ahli. Siswa kemudian diminta untuk kembali kekelompok asal, untuk menerangkan hasil diskusinya kepada teman kelompoknya dikelompok asal. Melalui kegiatan ini, maka siswa termotivasi sehingga aktivitas siswa dalam aspek kerjasama, keaktifan, dan rasa tanggungjawab siswa meningkat. Aktivitas siswa yang meningkat memiliki pengaruh kepada meningkatnya kemampuan pemecahan masalah matematis. Hal ini disebabkan karena pada pembelajaran matematika dengan kooperatif tipe Jigsaw, siswa secara aktif untuk mengkonstruksi pengetahuannya, siswa secara aktif mengeluarkan gagasanya sehingga pembelajaran lebih bermakna. Selain itu dengan adanya kegiatan kelompok, siswa lebih mudah dalam memecahkan masalah matematika, karena soal-soal yang diselesaikan dikerjakan bersama-sama dengan teman kelompok.

\section{Kesimpulan}

Berdasarkan hasil penelitian dapat diambil simpulan, kemampuan pemecahan masalah matematis siswa melalui pembelajaran Kooperatife Learning Tipe Jigsaw pada materi perkalian di kelas II SDN Tanjungsari 1 Kabupaten Sumedang mengalami peningkatkan hal ini terlihat dari hasil perolehan nilai kemampuan pemecahan masalah pada siklus I yaitu 65, mengalami peningkatan pada siklus II dengan nilai 80 . Begitu pula dengan aktivitas belajar siswa melalui pembelajaran Kooperatife Learning Tipe Jigsaw pada materi perkalian di kelas II SDN tanjungsari 1 Kabupaten Sumedang mengalami peningkatan, pada siklus I dengan nilai 60, mengalami peningkatan pada siklus 2 dengan nilai aktivitas yang diperoleh yaitu 81 .

Saran dalam penelitian ini, meskipun dalam penelitian ini setelah dilaksanakan pembelajaran matematika menggunakan pembelajaran kooperatif learning tipe Jigsaw kemampuan pemecahan matematika dan aktivitas belajar siswa mengalami peningkatan, perlu adanya penelitian lebih lanjut terhadap pembelajaran matematika 
dengan menggunakan kooperatif learninng tipe Jigsaw dalam meningkatkan kemampuan matematika yang lainya dan dalam materi matematika yang berbeda.

\section{Daftar Pustaka}

Anggo, Mustamin. (2011). "Pemecahan Masalah Matematika Kontekstual untuk Meningkatkan Kemampuan Metagognisi Siswa". Edumatica. Vol 01(02). 35-42.

Fachrurazi. 2011. "Penerapan Pembelajaran Berbasis Masalah untuk Meningkatakn Kemempuan Berpikir Kritis dan Komunikasi Matematis Siswa Sekolah Dasar". Forum Penelitian, Edisi khusus Vol 01(01). 7689.

Fuadi, dkk.(2016). "Meningkatkan Kemampuan Pemahaman dan Penalaran Matematis Melalui Pendekatan Kontekstual". Jurnal Didaktika Matematika. Vol. 3, (1). 47-54.

Hendriana, H. (2002). Meningkatkan Kemampuan Pengajuan dan Pemecahan Masalah matematika dengan Pembelajaran berbalik Studi: Eksperimen pada Siswa Kelas I Sekolah Menengah Umum negeri 23 Kota Bandung. Tesis. UPI: Bandung: Tidak Dipublikasikan

Isjoni. (2009). Cooperative Learning Efektivitas Pembelajaran Kelompok. Bandung: Alfabeta

Jacob, C. (tanpa tahun). Matematika Sebagai Pemecahan Masalah. [Online].
Tersedia:http://file.upi.edu/Direktori/ FPMIPA/JUR. PEND. MATEMATIKA/1 94507161976031CORNELIS JACOB/ MATEMATIKA SEBAGAI PEMECAHAN MASALAH.pdf. [6 September 2012]

Lidinillah. (2008). "Strategi Pembelajaran Pemecahan Masalah di Sekolah Dasar". Jurnal Pendidikan Dasar Universitas Pendidikan Indonesia. Vol 01(1). Tidak tersedia

Lie, Anita. (2007). Cooperative Learning Mempraktikkan Cooperative Learning di Ruang-Ruang Kelas. Jakarta: Grasindo

Saija, M. L. (2010). Pembelajaran Berbasis Masalah dengan Model Kooperatif Murder untuk Meningkatkan Kemampuan Pemecahan Masalah Matematis Siswa SMA: Studi Eksperimen Pada Siswa Kelas $X I$ IPA Lembang, Bandung). Tesis UPI. Bandung: Tidak Diterbitkan.

Sanjaya. (2006). Strategi Pembelajaran Berorientasikan Standar Proses Pendidikan. Jakarta: Kencana Predana Media Group

Suherman, et.al. (2001). Strategi Pembelajaran Matematika Kontemporer. Bandung: JICA-Universitas Pendidikan Indonesia

Suwangsih, E dan Tiurlina. (2006). Model Pembelajaran Matematika. Bandung: UPI PRESS 